\title{
Analysing The Entrepreneurial Competencies That Characterises The Success Of Female-Led Enterprises In Ghana
}

\author{
Cynthia Oduro-Nyarko \\ Department of Management and Public Administration \\ Accra Technical University \\ Dolores Mensah Hervie \\ Department of Management and Public Administration \\ Accra Technical University
}

\begin{abstract}
Micro, Small and Medium Enterprises (MSMEs) plays an important role in the economic development of a country. There are increasing numbers of women entrepreneurs involve in this sector in recent times. Entrepreneurial competencies have been validated in Entrepreneurship studies. Hence this paper examines the entrepreneurial competencies that influence the success of their businesses since the success or failure of the venture will be affected by the skills and abilities (competencies) of ownermanagers. A sample of 200 respondents were selected for a survey in Accra Metropolitan area of the Greater Accra region of Ghana. Structured questionnaire was used to collect data and using survey method. The data analysis was done using descriptive statistics. The findings of the study revealed that there is a significant positive relationship between entrepreneurial competencies and venture success.
\end{abstract}

Keywords: Entrepreneurship, Entrepreneurial Competencies, Women Entrepreneurs, Small and Medium Enterprises (SMEs), Business Success.

\section{INTRODUCTION}

A recent development in entrepreneurship research has given increased attention to femaleled enterprises (SMEs), largely due to the significant role women play in building the economy of nations. They are a great source of innovation and job creation, and Ghana is no exception. (Boohene et. al., 2008, Abor \& Quarter, 2010). Brush (2006) claims that women's participation in entrepreneurship is growing in most countries. Yet their failure rate is still high despite the considerable government support and assistance. Research shows that a large number enters and exit every year. The above situation suggests that there may be practical factors that inhibit the growth of female-led enterprises in developing countries (GEM 2016). Consequently it will be useful to investigate how these factors affect the operation of female entrepreneurs. Women entrepreneurship is being recognized as an important factor for economic growth and development in Ghana and other parts of the world. The Ghanaian female-led SMEs have the potential to contribute significantly to the Ghanaian economy. Empirical finding indicates that increase in women's income lead to higher spending on family welfare, often critical for reaching key national developmental goals (GEM 2013). With increasing number of women in the labour force and growing unemployment rate, entrepreneurship has become a great opportunity for women to earn their own income whiles helping others as they do it.

Entrepreneurship in the country is dominated by men, according to (GSS, 2015), six out of every $10(60.3 \%)$ persons engaged in business are males while female constitute the rest $(39.7 \%)$, and for most of the women who are in business their survival remains real problem as many lack professional abilities in managing their businesses as compared to men. Several 
studies appear to validate gender differences in business outcomes for female and male entrepreneurs. They come across different samples of firms within different business sectors (Du Rietz \& Henrekson, 2000; Ruane \& Sutherland, 2007). For example (Yusuff et. al. 2016) posited that possible explanation of entrepreneurial earnings gap in gender differences includes: human capital, start-up capital and social capital, preferences, motivations and household production. For instance while there are limitations in information or reliable statistics on female-led enterprises as compared to their male counterpart, they are often viewed as representing activities in the informal sector. The majority of their businesses are microenterprises, employing less than 10 people and hence their general input to total employment. Women entrepreneurs tend to operate smaller businesses; use less finance; operate in more competitive industry sectors with lower returns and survival rates; and undertake more household duties in addition to their business activities. A host of problems makes it difficult for female entrepreneurs to exploit the existing potentials for further employment and wealth creation. They are faced with the issues of lack of appropriate knowledge and skills, limited access to relevant information on technology, limited access to finance and cultural barriers. Literature suggests that one of the obstacles to the success of female SMEs is the limited capabilities in terms of attitude, motivation, experience, skills and exposures of the entrepreneurs who operate these businesses (Boohene, Kotey \& Sheridan, 2008). Narrowing the gap in terms of entrepreneurial activities remains a priority focus for policy makers in all economies. (GEM, 2016).

Research indicates that most of SMEs failure is as a result of owner-managers incompetence, inadequacy and inexperience in managing their businesses (Ropega, 2011; Griffin, 2012) and proposed entrepreneurial competencies as a success factor. Despite the fact that research evidence suggest that entrepreneurial competencies is a crucial driver for business success (Man et al, 2002; Man, Lau, et. al., 2008; Mitchelmore \& Rowley, 2010; Ahmad et al., 2010), there are still limitations in the literature relating to the entrepreneurial competencies of Ghanaian entrepreneurs, especially female entrepreneurs. There has been limited research conducted (if any) to unravel entrepreneurial competencies that relates to the success of female-led enterprises in Ghana. Therefore, the problem this study addresses is to examine the entrepreneurial competencies that characterize the success of female-led enterprises in Ghana by drawing on the competency-based approach.

\section{Female Entrepreneur}

\section{LITERATURE}

A female entrepreneur is described as the female head of a business unit, who has taken the initiative to launch a new business. She accepts the accompanying risk, financial, administrative and social responsibility and takes charge of the day to day running of the business. Female-led businesses have made significant contributions to their respective economies all over the world. Most of these women operate in micro and small enterprises and are mainly dominant in the retail and service industry. (Hisrich \& Brush, 1984; GEM, 2013). They are small in size with low growth profile (Ekpe, 2011; GEM, 2013). It has been recognized that women are acquiring spaces in the labour market and the rate at which they are founding businesses is more than that of their male counterparts (GEM, 2012;2016) and their number is rising more and more. Recent focus on the role of women entrepreneurs is as a result of their contribution to economic development and also for their contribution to the diversity of entrepreneurship in economic process through innovation and job creation.

Studies by Hisrich, Brush, Good and DeSouza (2007) pointed out that SMEs in general and women-owned enterprises, in particular are of increasing importance to the US economy, given their revenues, number of employees, and the self-employment generated. Although the 
formation of businesses by women has increased significantly, the rates of women entrepreneurial activity are significantly lower than those of their male counterparts. They are disadvantage in their access to various entrepreneurial capitals due to their personal background, employment experiences, their socio-economic background and the cultural context in which they operate their businesses. (Carter and Shaw, 2006).

According to Chamlee-Wright (1997), in Ghana entrepreneurship provides a means of poverty alleviation especially, for women who generally have less of a chance of employment. The GEM report (2010) on Women Entrepreneurship indicates that generally women's participation in entrepreneurship is low, but in Ghana, more than half of entrepreneurs are women. They attributed $55 \%$ as proportion of women-owned businesses. The report says that in Ghana for every 5 male entrepreneurs, there are 6 women entrepreneurs and this is motivated by necessity. In Ghana, SMEs constitute about $90 \%$ of all enterprises as opine by (Boohene et al, 2008) and (Abor and Biekpe, 2006) and women constitute the vast majority of these small businesses and they are found mostly in the retail and service sectors (Saffu \& Manu, 2004). They are found to be less resilient, characterized by difficulty in accessing finance, are less informed and appear to exhibit a lower survival rate (Boohene et al., 2008). On the average, women-owned enterprises generate lower sales revenue than men-owned enterprises (GEM, 2015). This study is important as it highlights those competencies that characterize the performance of these female entrepreneurs.

\section{Entrepreneurial Competencies}

In establishing the factors that determines business success and growth in SMEs, some researchers have undertaken to study the behavior of the entrepreneur by examining the managerial work of successful entrepreneurs. Two main approaches have been adopted. The first focus on personality trait profile of the entrepreneur, known as the trait approach (Entrialgo et al., 2001; Rauch \& Freese, 2007\}. The second focus on the competencies of the individual entrepreneur, known as the competency approach. (Chell 2013; Tan \& Tan 2012; Thongpoon et al., 2012). Man et. al. (2002) defined entrepreneurial competencies as higherlevel characteristic encompassing personality traits, skills and knowledge. Entrepreneurial competencies according to Bird (1995) is referred to as an underlying characteristic such as generic and specific knowledge, motives, traits, self-image, social roles and skill which results in venture birth, survival and/or growth. Lazar and Paul (2015) puts entrepreneurial competencies as the underlying characteristics possessed by individuals which assist them to execute the tasks in a manner that is most befitting. Many authors have used the six competencies which are positively related to the performance of the business. These six competencies areas are: opportunity competencies, organising competencies, strategic competencies, relationship competencies, commitment competencies and conceptual competencies were adopted in this study.

Opportunity competencies: Competencies related to opportunity identification and developing market opportunities through various means. (Man et al. 2002)

Organizing competencies: Competencies relates to the organization of different internal and external resources (human, physical, financial and technological) including team-building leading employees, training and controlling. (Man et al., 2002)

Strategic competencies: Competencies related to setting, evaluating and implementing the strategies of the firm. (Man et. al., 2002) 
Relationship competencies: Competencies related to person-person or individual to groupbased interaction using contacts, connections, persuasive ability, communication and interpersonal skills. (Man et. al., 2002)

Commitment competencies: Competencies related to the force that drives the entrepreneur to move ahead with the business. (Man et. al., 2002)

Conceptual competencies: Competencies related to decision-making skill, absorbing and understanding complex information, and risk-taking and innovation. (Man et. al., 2002)

Namusonge, (2014) using a survey method to collect data on 60 Kenyan exporting small and medium -sized enterprises found out that while some competencies are equally important among exporting SMEs, others are not equally important. They used various sectors within the sample; some competencies were found to be more important in some sectors than in others. Her results show that leadership, strategic thinking and organization knowledge are crosssector or core competencies and they applied regardless of the function or type of organization. The services sector competed mostly by the differentiation strategy; the manufacturing sector competed mostly on the low-cost strategy while most of the firms in the agricultural sector employed the focus strategy.

Mitchelmore and Rowley (2010) using a theoretical revision on competencies organized a chart with five categories of analysis of these competencies. They put them into entrepreneurial (that is a focus on innovation); businesses and managerial (that is a focus on the development of resources and operational and strategic aspects). Other are human relations (that is a focus on culture, leadership and persons); and conceptual and relationship (that is a focus on communication, relationship with stakeholders and decision-making).

Xian Li (2009) to text hypothesis that entrepreneurs possess a higher level of entrepreneurial competencies than the non-entrepreneurs; and the entrepreneurs and the non-entrepreneurs can be discriminated based on their entrepreneurial competency level; the conducted research among business owners and manager. By employing discriminate analysis, their study found out that the business owners possessed a higher level of entrepreneurial competencies than the managers. It discovered that the business owners and managers could discriminate based on their entrepreneurial competency level which supported their hypothesis.

\section{Competencies of Women Entrepreneurs}

Mitchelmore and Rowley (2013) in a questionnaire based survey of 210 female entrepreneurs in England and Wales, their findings identified women entrepreneurs by these cluster of competencies; personal and relationship competencies, business and management competencies, entrepreneurial and human relation competencies. Their study shows that women place more value on these clusters of competencies.

Pamela and Illigan (2012) using the descriptive approach, the study found that rural women entrepreneurs in the Philippines are high in the goal setting, information seeking, and systematic planning and monitoring competencies. They can maintain work-life balance through proper time management and to strive to spend more time with family members through a wide array of activities done together with their spouses and children.

Jennings and Cash (2006) in a review of literature pointed out that empirically female business owners may differ from their male counterpart when it comes to their motivation, social and human capital, goals and success, their growth orientation, strategic choices and the use of 
financial capital. There is the assertion that when it comes to financial competencies, women may be weaker than that of men. The women regularly rate themselves as less competent in financial skills than their male counterpart.

There is evidence of a link between entrepreneurial competencies and business success. Though entrepreneurial competencies are important to all SMEs, the urge to understand such competencies in the context of female entrepreneurs is of particular interest as there are a growing number of businesses owned by women that play a significant role in various economies.

A study of 220 Israeli women entrepreneurs by Lerner and Almor 2002 through factor analysis found out that managerial skills (finance, human resources management, operations and strategic management) and entrepreneurial skills (innovation and marketing) are separate elements.

\section{Venture Success}

An entrepreneurial venture is successful if it is growing and the goal of every business is to be successful. The measures used in the literature include profitability, growth in employees and sales revenue. Profitability is an essential indicator of business success. For owners of SMEs, profit flows direct to owners as the businesses are privately owned by them as literature suggests (Abor \& Beikpe 2006; Haber \& Reichel, 2005). Studies show that firm growth is an addition to firm performance (Haber \& Reichel, 2005) but that women-owned SMEs are likely to grow due to lack of human and financial resources, (Welter et al. 2003). Research evidence from Ghana suggest that women are less likely than their male counterpart to avoid to employ debt capital due to disparity in access to loan facilities. (Abor \& Beikpe, 2006), and this normally affects their venture success and growth.

\section{Entrepreneurial Competencies and Venture Success}

Naledi and Rambe, (2014) conducted a research based on the Global Entrepreneurial Monitor report of South Africa, (GEM, 2013, 2012, and 2010). They use a case study approach to examine the relationship between the managerial competencies of managers/owners and the performance of emerging internet firms in the Free State region, of South Africa. Their model suggests that an assortment of managerial competencies (innovative capabilities, market management capabilities, human capital requirements, technical knowledge, skills, abilities, as well as financial literacy, strategic planning and marketing) is critical to the performance and survival of small internet business.

Sanchez (2012) conducted a study on the influence of entrepreneurial competencies on the performance of small enterprises by building a causal model using data obtained from Spanish entrepreneurs. The results indicate that entrepreneurial competence plays an influential role in organizational capabilities affects the firm performance positively and it partially mediates the relationship between entrepreneurial competence and firm performance. It concluded that although the competitive scope is not significantly related to business growth, it is a strong predictor of other performance.

Neeley and Van, (2010) posits that although women entrepreneurs have grown in large numbers across the globe over the last decade and there has been increase in their entrepreneurial potentials, there are still limits when it comes to the issue of growth of their businesses. Empirical evidence shows that the performance and growth indicators of firms owned and managed by women is lower than that of firms owned by men. 
According to Lerner and Almor (2002) in a study of Israeli women, there are four main factors that explain the performance of women-owned enterprises namely: industrial competency, management competency, strategic planning competency, and organizational resources. They asserted that lack of these inherent competencies in female entrepreneurs represents a more serious barrier to their venture growth than those external obstacles women face as entrepreneurs.

\section{RESEARCH METHODS}

The research design adopted for this study was the descriptive survey. A cross-sectional design was used to examine the effect of entrepreneurial competencies on venture success of women entrepreneurs. Using the systematic sampling technique, a sample size of 200 women entrepreneurs were drawn from the Greater Accra Region, precisely from the Accra Metropolis. The sample contains SMEs in different sectors, for example, the manufacturing, service and trade, agro-processing. The NBSSI provided the list of micro enterprises. They are all registered as members of the NBSSI. A structured questionnaire was used to collect primary data. The structural equation model was used to analyzed the data.

\section{RESULTS AND FINDINGS}

Table 1: Demographic characteristics of respondents

\begin{tabular}{lll}
\hline Variables & $\mathrm{N}$ & $\%$ \\
\hline Age & & \\
$21-30$ & 62 & $42.5 \%$ \\
$31-40$ & 54 & $37.0 \%$ \\
$41-50$ & 21 & $14.4 \%$ \\
$51-60$ & 8 & $5.5 \%$ \\
above 60 & 1 & $.7 \%$ \\
Marital Status & & \\
Single & 77 & $53.5 \%$ \\
Married & 52 & $36.1 \%$ \\
Divorced & 8 & $5.6 \%$ \\
Separated & 1 & $.7 \%$ \\
Widow & 6 & $4.2 \%$ \\
Educational Level & & \\
None & 4 & $2.7 \%$ \\
JHS & 27 & $18.5 \%$ \\
SHS & 33 & $22.6 \%$ \\
Diploma & 36 & $24.7 \%$ \\
Bachelor & 25 & $17.1 \%$ \\
Masters & 18 & $12.3 \%$ \\
PHD & 3 & $2.1 \%$ \\
\hline
\end{tabular}


Table 2: Descriptive Statistics of Strategic Competencies

\begin{tabular}{llll}
\hline Strategic Competencies & $\mathrm{N}$ & Mean & SD \\
\hline Identify long term issues, problems or opportunities & 142 & 4.3 & .867 \\
Be aware of the projected directions of the industry and & 140 & 4.2 & .874 \\
how changes might impact my business & & & \\
Prioritize work in alignment with business goals & 144 & 4.5 & .850 \\
Redesign my business to better meet long term objectives & 140 & 4.2 & .840 \\
and changes & & & \\
Align current actions with strategic goals & 142 & 4.2 & .778 \\
Assess and link short term, day to day tasks in the context & 138 & 4.3 & .788 \\
of long term direction & & & \\
Monitor progress toward strategic goals & 143 & 4.3 & .822 \\
Evaluate results against strategic goals & 142 & 4.2 & .919 \\
Determine strategic actions by weighing costs and benefits & 137 & 4.4 & .664 \\
Conduct research before proceeding with an investment & 142 & 4.2 & .857 \\
Forecast trends in business & 143 & 4.4 & .835 \\
Create a competitive edge & 142 & 4.4 & .839 \\
\hline
\end{tabular}

Table 2 shows the strategic entrepreneurial competencies of the owner-managers of the SMES. As shown in the table, the owner-managers of the SMEs identify long term issues, problems or opportunities $(M=4.3, S D=.867)$, are aware of the projected directions of the industry and how changes might impact their businesses $(M=4.2, S D=.874)$, and also able to prioritize their work in alignment with their business goals $(M=4.5, S D=.850)$. On the other hand, the owner-managers of the SMEs indicated that they are able to redesign their business to better meet their long term objectives $(M=4.2, S D=.840)$, align their current actions with strategic goals $(M=4.2, S D=.778)$, as well as assess and link short term, day to day tasks in the context of long term direction $(M=4.3, S D=.788)$. Meanwhile, the owners-managers reported that they monitor their progress toward their strategic goals $(M=4.3, S D=.822)$, and evaluate the results achieved against their strategic goals $(M=4.2, S D=.919)$. They also indicated that they determine strategic actions by weighing costs and benefits $(M=4.4, S D=$ $.664)$, conduct research before proceeding with an investment $(M=4.2, S D=.857)$, forecast trends in business $(M=4.4, S D=.835)$, to create a competitive edge $(M=4.4, S D=.839)$.

Table 3: Descriptive Statistics of Commitment Competencies

\begin{tabular}{llll}
\hline Commitment Competencies & $\mathrm{N}$ & Mean & SD \\
\hline Dedicate to make the business work & 141 & 4.4 & .77 \\
Refuse to let the business fail & 141 & 4.5 & .73 \\
Have an extremely strong internal drive to succeed & 142 & 4.4 & .76 \\
Commit to long term business goals & 141 & 4.4 & .73 \\
Be committed to producing quality goods or services & 142 & 4.8 & .78 \\
\hline
\end{tabular}

Table 3 shows the results of the owner-managers response to their commitment competencies. As shown in the table, the owners-managers indicated that they dedicate themselves to make their business $\operatorname{work}(M=4.4, S D=.77)$, refuse to let their business fail $(M=4.5, S D=.73)$, and have an extremely strong internal drive to succeed $(M=4.4, S D=.76)$. On the other hand the owner-managers reported that they are committed to their long term business goals $(M=$ $4.4, S D=.73)$ and to also to producing quality goods and services $(M=4.8, S D=.78)$. 
Table 4: Descriptive Statistics of Conceptual Competencies

\begin{tabular}{llll}
\hline Conceptual Competencies & $\mathrm{N}$ & Mean & SD \\
\hline $\begin{array}{l}\text { Understand the broader business implications of } \\
\text { ideas, issues and observations }\end{array}$ & 139 & 4.7 & .49 \\
$\begin{array}{l}\text { Translate ideas, issues and observations into the } \\
\text { business context }\end{array}$ & 138 & 4.4 & .59 \\
Take reasonable job-related risks & 142 & 4.2 & .88 \\
Monitor progress toward objectives in risky actions & 141 & 4.2 & .94 \\
Look at old problems in new ways & 145 & 4.2 & .81 \\
Explore new ideas & 145 & 4.3 & .88 \\
Treat new problems as opportunities & 140 & 4.3 & .83 \\
Innovate and do things differently & 142 & 4.6 & .75 \\
Be proactive and responsive to changes & 141 & 4.3 & .73 \\
Find ways to commercialize ideas & 139 & 4.2 & .79 \\
Be spontaneous and quick in making decisions & 140 & 4.5 & .75 \\
\hline
\end{tabular}

Table 4 shows the conceptual competencies of the owner-managers of the SMEs. As shown in the table, the owner-managers: understand the broader business implications of ideas, issues and observations $(M=4.7, S D=.49)$; translate ideas, issues and observations into the business $\operatorname{context}(M=4.4, S D=.59)$; take reasonable job-related $\operatorname{risks}(M=4.2, S D=.88)$; monitor progress toward objectives in risky actions $(M=4.2, S D=.94)$; look at old problems in new ways $(M=4.2, S D=.81)$; explore new ideas $(M=4.3, S D=.88)$; treat new problems as opportunities $(M=4.3, S D=.83)$; innovate and do things differently $(M=4.6, S D=.75)$; be proactive and responsive to changes $(M=4.3, S D=.73)$; find ways to commercialize ideas $(M=4.2, S D=.79)$; and be spontaneous and quick in making decisions $(M=4.5, S D=.75)$.

Table 5: Descriptive Statistics of Opportunity Competencies

\begin{tabular}{llll}
\hline Opportunity Competencies & $\mathrm{N}$ & Mean & SD \\
\hline Identify goods or services that the customer wants & 140 & 4.3 & .88 \\
Perceive unmet consumer needs & 145 & 4.2 & .89 \\
$\begin{array}{l}\text { Actively look for products or services that provide } \\
\text { real benefit to customers }\end{array}$ & 142 & 4.3 & .84 \\
Seize high quality business opportunities & 137 & 4.1 & .78 \\
Take an idea and make something out of it & 141 & 4.3 & .84 \\
Scan the environment to look for opportunities & 140 & 4.3 & .83 \\
\hline
\end{tabular}

Table 5 shows the opportunity competencies of the owner-managers of the SMEs. The ownermanagers are able to identify goods and services that customer wants $(M=4.3, S D=.88)$, perceive unmet consumer needs $(M=4.2, S D=.89)$, and actively look for products or services that provide real benefits to customers $(M=4.3, S D=.84)$. On the other hand, the ownermanagers seize high quality business opportunities $(M=4.1, S D=.78)$, take an idea and make something out of it $(M=4.3, S D=.84)$, and scan the environment to look for opportunities $(M=4.3, S D=.83)$. 
Table 6: Descriptive Statistics of Organizing and Leading Competencies

\begin{tabular}{llll}
\hline Organizing and Leading Competencies & $\mathrm{N}$ & Mean & $\mathrm{SD}$ \\
\hline Plan the operations of the business & 142 & 4.4 & .76 \\
Plan the organization different resources & 142 & 4.4 & .75 \\
Keep the organization running smoothly & 142 & 4.3 & .86 \\
Organize resources & 140 & 4.4 & .69 \\
Coordinate tasks & 140 & 4.5 & .56 \\
Supervise subordinates & 140 & 4.1 & .95 \\
Lead subordinates & 144 & 4.2 & .80 \\
Organize people & 145 & 4.2 & .84 \\
Motivate people & 143 & 4.4 & .74 \\
Delegate effectively & 141 & 4.2 & .84 \\
Get the right people on board & 140 & 4.7 & .35 \\
Energize the team to work towards goals & 142 & 4.4 & .79 \\
Build an entrepreneurial culture in which my staff & 139 & 4.2 & .95 \\
are willing to take risks & & &
\end{tabular}

Table 6 shows the organizing and leading competencies of the owner-managers of the SMEs. As shown in the table, the owner-managers: plan the operations of their businesses $(M=$ $4.4, S D=.76)$; plan the organization of different resources $(M=4.4, S D=.75)$; keep the organization running smoothly $(M=4.3, S D=.86)$; organize resources $(M=4.4, S D=.69)$; coordinate tasks $(M=4.5, S D=.56)$; supervise subordinates $(M=4.1, S D=.95)$; lead subordinates $(M=4.2, S D=.80)$; organize people $(M=4.2, S D=.84)$; motivate people $(M=4.4, S D=.74)$; delegate effectively $(M=4.2, S D=.84)$; get the right people on board $(M=4.7, S D=.79)$; energize the team to work towards goals $(M=4.4, S D=.79)$; build an entrepreneurial culture in which my staff are willing to take risks $(M=4.2, S D=.95)$.

Table 7: Descriptive Statistics of Relationships Competencies

\begin{tabular}{llll}
\hline Relationships Competencies & $\mathrm{N}$ & Mean & SD \\
\hline Develop long term trusting relationships with others & 140 & 4.2 & .81 \\
Negotiate with others & 144 & 4.2 & .90 \\
Interact with others & 144 & 4.5 & .81 \\
Maintain a personal network of work contacts & 143 & 4.3 & .80 \\
Communicate effectively with others & 145 & 4.4 & .82 \\
Select the right people for advice & 142 & 4.2 & .87 \\
Create a positive work climate through discussion & 139 & 4.3 & .75 \\
and problem-sharing & & & \\
\hline
\end{tabular}

Table 7 shows the relationship competencies of the owner-managers of the SMEs. The ownermanagers are able to develop long term trusting relationship with others $(M=4.2, S D=.81)$, are able to negotiate $(M=4.2, S D=.90)$, and interact with others $(M=4.5, S D=.81)$. On the other hand, the owner-managers are able to maintain a personal network of work $\operatorname{contacts}(M=4.3, S D a=.80)$, communicate effectively with others $(M=4.4, S D=.82)$, select the right people for advice $(M=4.2, S D=.87)$, and create a positive work climate through discussion and problem-sharing $(M=4.3, S D=.75)$. 


\section{CONCLUSION}

This study was designed to examine the role of entrepreneurial competencies, i.e. opportunity, organizing, relationship, strategic, commitment, and conceptual in the venture success of women entrepreneurs in the SMEs sector in Accra metropolis of Ghana. The study contributes to research on entrepreneurship by revealing that entrepreneurial competencies play an important role in enhancing venture success. The findings from the study also confirm the validity of the model of Man et al (2002) in addressing the relationship between entrepreneurial competencies and SMEs performance. It highlights on the important role the owner-manager play in the determination of venture success and growth of SMEs over and above environmental factors. All the six competency areas (ie. Opportunity, organizing, relationship, strategic, commitment and conceptual) have a positive impact on venture success. This suggests the need to have higher entrepreneurial competencies which allow entrepreneurs to develop superior strategies and identify new business opportunities. The study discovered that majority of the women entrepreneurs were not in paid employment before starting their own business. This indicates that they were new entrants into business which may be as result of unemployment before starting their businesses. Cooperation may enable the women entrepreneurs to improve their strategic position and therefore should ensure they have built a strong social network and good government relationship in order to ensure their business success. Government should pay more attention to women entrepreneurs by giving them adequate support for their businesses in the form of training, credit accessibility to alleviate poverty.

\section{References}

Abor, J. \& Biekpe, N. (2006). A comparison of male-owned and female-owned businesses in Ghana, Entrepreneurship and Innovations

Abor, J. \& Quartey, P. (2010). Issues in SME Development in Ghana and South Africa. International Research Journal of Finance and Economics ISSN 1450 -2887 issue 39

Ahmad, N.H., Ramayah, T., Wilson, C., \& Kummerow, L., (2010). Is Entrepreneurial Competency and Business Success Relationship Contingent Upon Business Environment? A Study of Malaysian SMEs. International Journal of Entrepreneurial Behaviour and Research 16(3), 2010, pp 182-203

Bird, (1995). Towards a theory of entrepreneurial competency. Advances in Entrepreneurship, Firm Emergence and Growth, 2. Pp51-72

Boohene, R., Sheridan, H. \& Kotey, B (2008). Gender, Personal Values, Strategies and Small Business performance: A Ghanaian case study. Equal opportunity International, vol 27, issue 3 pp. 237 -257

Carter, S. \& Shaw, E. (2006). Women's Business Ownership: Recent research and policy developments. UK: Small Business Service.

Chamlee-Wright, E. (1997). Cultural Foundations of Economic Development: Urban Female Entrepreneurship in Ghana, New York, Routledge.

Chell, E. (2013). "Review of Skills and the Entrepreneurial Process", International Journal of Entrepreneurial Behaviour and Research. 19(1), 6-31

Dzisi, S \& Seddoh, J.E. (2009). Human and Financial Capital Factors In Entrepreneurial Success of Ghanaian Women: A Developing Country Perspective. Journal of Business and Enterprise Development. 1(1), $102-118$.

Du Rietz, A., \& Henrekson, M. (2000). Testing the female underperformance hypothesis. Small Business Economics $14,1-10$.

Ekpe, I., (2011). Women Entrepreneurs and Economic Development in Nigeria: Characteristics for Success. International Journal of Business Social Science. Vol. 2 No. 1

Entrialgo, M., Fernandez, E \& Vazquez, C.J. (2001). The effect of organizational context on SME's entrepreneurship: some Spanish evidence, Small Business Economics, 16(3), 223-236.

Ghana Statistical Services (2010). Population and Housing Census. Retrieved from www.statsghana.gov.gh/docfiles/.../National_Analytical_Report 
Ghana Statistical Services (2015). Population and Housing Census. Retrieved from www.gh.undp.org/.../ghana/.../UNDP_GH_

Global Entrepreneurship Monitor (2012). African Entrepreneurship: Sub-Saharan African Regional Report by Mike, H \& Donna, Kelly. International Development Research Center. Available at www.gemconsortium.org. Global Entrepreneurship Monitor (2013). Promoting Entrepreneur: Insight for Policy, Ghana Policy Highlight. Global Entrepreneurship Monitor (2014). Available at www.gemconsrtium,org.

Global Entrepreneurship Monitor (2015). Available at www.gemconsrtium,org.

Global Entrepreneurship Monitor (2016). Women and Youth Spearheading Business Creation. High-Impact Entrepreneurship Global Report by: Morris Rhett.

Griffin, R.W. (2012). Managing New Venture Formation and Entrepreneurship. In Griffin, R.W. (ed.) Management: Principles and Practices: South-Western, Cengage Learning.

Haber, S. \& Reichel, A. (2005). Identifying the performance measures of small tourism ventures - the case of the tourism industry. Journal of Small Business Management 43 (3), 237-286

Hisrich, R.D. \& Brush, C.G. (1984). The Women Entrepreneurs: Management Skills and Business Ownership. Gender, Work and Organization, 10(4), 433-54.

Hisrich, R. D., Peters, M. P. \& Shepherd, D.A. (2013). Entrepreneurship. (9th Ed.). African Edition. McGraw-Hill, Irwin.

Jennings, J.E. \& Cash, M.P. (2006). Women's entrepreneurship in Canada: Progress, puzzles and priorities. In C.G. Brush, N.M. Carter, E.J. Gatewood, P.G. Greene, \& M.M. Hart (Eds.), Growth-oriented women entrepreneurs and their businesses-A global research perspective (pp. 53-87). Cheltenham, UK: Edward Elgar.

Lazer N, \& Paul, G. (2015). Entrepreneurial Competencies effect on SMEs Performance through the mediating effect of Psychological contracting of outsourcing. International Journal of Business and Economic development, $3(2)$

Lerner, M \& Almor, T. (2002). Relationships among Strategic Capabilities and the Performance of Women-Owned Small Ventures. Journal of Small Business Management. 40(2), 109-125

Man, T.W.Y., Lau, T. \& Chan, K.F. (2002). The competitiveness of small and medium enterprises: a conceptualization with focus on entrepreneurial competencies. Journal of Business Venturing, 17(2), 123-142

Man, T.W.Y., Lau, T. \& Snape, E. (2008). Entrepreneurial competencies and the performance of small and medium enterprises: An investigation through a framework of competitiveness. Journal of Small Business and Entrepreneurship, 21(3), 257-276

Mcmahon, R.G. (2001). Growth and performance of manufacturing SMEs: The influence of financial management characteristics. International Small Business Journal, 19(3), 10-20

Mitchelmore, S., \& Rowley, J. (2010). Entrepreneurial competencies: a literature review and development agenda. International Journal of Entrepreneurial Behaviour and research, 16(2), 92-111.

Mitchelmore, S., \& Rowley, J. (2013). Entrepreneurial competencies of women entrepreneurs pursuing growth, Small Business and Enterprise Development. Vol.20, No. 1,125-142

Naledi, M \& Rambe, P. (2014). Relationship between managerial competencies of owner-managers of emerging technology firms and business performance: A case of internet cafes in Mangaung Province in South Africa. Advance in Social Science, Economics and Management Study

Namusonge, M.J. (2014). Linking Competencies with strategies: The case of small and medium-sized exporting firms in Kenya. International Journal of social Sciences and Entrepreneurship, 1(11), 418-439.

Neeley, L., and Van A, H. (2010), 'Differences between female and male entrepreneurs' use of bootstrap financing', Journal of Developmental Entrepreneurship, Vol. 15, No.1: 19-34

Rauch, A. \& Frese, M. (2007). "Let's put the person back into entrepreneurship research: A meta-analysis on the relationship between business owners' personality traits, business creation, and success," European Journal of Work and Organizational Psychology, 16(4), 353-385.

Ropega, J. (2011). The Reasons and Symptoms of Failure in SME. International Advances in Economic Research, $17(4), 476-483$. 
Saffu, K. \& Takyiwa-Manu, (2004). Strategic Capabilities of Ghanaian Female Business Owners and the Performance of their Ventures. Html version of http:/www.nwbc.gov.documents/ICSB -Best Paper

Sánchez, J. (2012). The Influence of Entrepreneurial Competencies on Small Firm Performance. Revista Latinoamericana de Psicología, 44(2), 165-177

Tan, Wee-Liang \& Samuel T. Tan (2012). 'Entrepreneurs, Managers and the Competency Approach: Do Entrepreneurial Competencies Differentiate Entrepreneurs from Managers?', available at SSRN 2128318.

Thongpoon, S, Noor H, Ahmad, \& Sofri Y, (2012). "Sustainable Performance of Thai SMEs: Investigating the Entrepreneurial Competencies and Sufficiency Economy Philosophy," Asia Pacific Journal of Management and Entrepreneurship Research, 1(2), 5-20.

Welter, F. (2006). Women entrepreneurship in Germany: State of the art, progress and open questions. In C.G. Brush, N.M. Carter, E.J. Gatewood, P.G. Greene, \& M.M. Hart (Eds.), Growth-oriented women entrepreneurs and their businesses-A global research perspective (pp. 128-153). Cheltenham, UK: Edward Elgar.

Yusuff, Y.Z.M., Baka, A.A. \& Ahmad, S. (2016). Determinant Factors of Women Entrepreneurs' Business Performance: A Conceptual Framework. Journal of Global Business and Social Entrepreneurship. Vol 1 no. 1, 5567

Xiang, L. (2009). Entrepreneurial Competencies as an Entrepreneurial Distinctive. An examination of the Competency Approach in Defining Entrepreneurs. Singapore Management University. 